\title{
UMA (POSITIVA) HETEROGENEIDADE DE INTERPRETAÇÕES SOBRE OS BLOCOS HISTÓRICOS DO ESPORTE BRASILEIRO: RESENHA DA OBRA HISTÓRIA DO ESPORTE NO BRASIL - DO IMPÉRIO AOS DIAS ATUAIS
}

\author{
A (POSITIVE) HETEROGENEITY OF INTERPRETATIONS ABOUT THE \\ HISTORICAL BLOCKS OF BRAZILIAN SPORTS: REVIEW OF THE BOOK \\ HISTÓRIA DO ESPORTE NO BRASIL - DO IMPÉRIO AOS DIAS ATUAIS
}

\author{
DEL PRIORE, MARY; MELO, VICTOR ANDRADE (ORGS.). HISTÓRIA DO \\ ESPORTE NO BRASIL: DO IMPÉRIO AOS DIAS ATUAIS. SÃO PAULO: EDITORA \\ UNESP, 2010.
}

\author{
Maria Thereza Souza* \\ André Mendes Capraro
}

Ao ler o título da obra, o leitor - principalmente aquele inserido no meio acadêmico - provavelmente deverá se questionar se a proposta dos organizadores Mary Del Priori e Victor Andrade de Melo não seria ousada demais. Ora, o esporte brasileiro, da sua gênese à atualidade, compreende nada mais nada menos que centenas de práticas e modalidades por um período de estimativamente dois séculos. Qual seria, então, a estratégia metodológica para organização deste livro de título tão pretensioso?

Era evidente que os dois pesquisadores responsáveis pela organização do livro, figuras reconhecidas em suas respectivas áreas - História e Educação Física -, não recorreriam ao antigo paradigma da história totalizadora. Tanto o ecletismo na seleção dos autores que iriam colaborar na formulação da obra, quanto a própria produção pessoal da dupla aponta para outro tipo de solução ao problema da macro-delimitação espaço-temporal do objeto.

A estratégia dos coordenadores da obra foi, portanto, a de estabelecer uma criteriosa seleção de temáticas que assertivamente comportou os principais "blocos históricos" do esporte no país. Em termos organizativos optou-se pelo simples, mas eficiente

\footnotetext{
" Doutoranda em Educação Física - UFPR. CEPELS - UFPR. Grupo de Pesquisa Futebol e Sociedade.

“" Pós-Doutor na Universitá Ca’ Foscari Venezia, Unive, Itália. Doutor em História - UFPR. Professor Adjunto - UFPR. CEPELS - UFPR. Grupo de Pesquisa Futebol e Sociedade.
}

ordenamento cronológico, iniciado com as antigas práticas de montaria e jogos derivados que remetem ao período imperial (inclusive com origem no Brasil colônia), texto da própria organizadora Mary Del Priore; até o tempo presente, com temáticas emergentes como os megaeventos esportivos ou a prática de esportes radicais.

O leitor familiarizado com a temática constatará que os eixos historiográficos transversais, centrais ao entendido no esporte no país, foram contemplados: os jogos e atividades competitivas típicas do período colonial; a incorporação de hábitos e costumes europeus (especialmente da França e Inglaterra); o movimento médico-higienista; o predomínio do ideal eugênico durante o Estado Novo, o discurso cientificista na Educação; a relação constante com a Educação Física; a correlação com a política (especialmente durante os regimes ditatoriais); a influência na "construção" de corpos e de um novo ideal de beleza; o exemplo como atividade globalizada e transnacional; enfim...

Os organizadores foram criteriosos e sagazes na seleção de temáticas e o ordenamento foi homogêneo, passando ao leitor um sentido de continuidade, porém, prudentemente, Victor Melo e Mary Del Priori, não impuseram aos autores uma linha teórica mestra ou uma padronização dos procedimentos metodológicos. Tal postura, assertiva, assegurou maior capacidade de desenvolvimento argumentativo e, consequentemente, 
conclusões criativas e inéditas. Por outro lado, o leitor, devido ao tom eclético em se tratando de matrizes teóricas que permeiam o campo historiográfico, pode ter a sensação de certa "vertigem" devido a quantidade de interpretações tão díspares. Problema necessário, tendo em vista o processo de especialização em que se passa as ciências de forma geral na atualidade, o qual a história não é isenta.

Tamanha abrangência de métodos, técnicas e procedimentos teóricos não deixaria de explicitar determinados conflitos. No capítulo Os anos 80, a juventude e os esportes radicais, o autor Rafael Fortes explicita nas suas considerações finais que...

É espantoso - para dizer o mínimo - o número de trabalhos que usam como referência principal a teoria dos campos de Bourdieu e dois ou três artigos seus sobre a sociologia do esporte, fato que se torna ainda mais grave ao considerarmos a variedade (quanto a fontes, perspectivas, objetos, abordagens e disciplinas) dos estudos que lançam mão do autor. Sem entrar no mérito da validade das teorias de Bourdieu para o tratamento de quaisquer objetos (incluindo o esporte) a simples existência de tanta gente abrigada sob o mesmo guarda-chuva sugere a existência de um problema Buscar a construção de referenciais novos ou o diálogo com teorias que ainda não foram usadas para discutir o esporte parece-nos muito mais instigante e potencialmente frutífero do que a mera tentativa de legitimação acadêmica a partir da citação do sociólogo francês de renome que, em sua vasta e importante obra, escreveu textos pouco relevantes e numerosos tratando do esporte. Esta observação geral se torna ainda mais válida e enfática se os esportes radicais forem o objeto de estudo (p. 449-450).

Ora, apresentado os argumentos contrários à utilização indiscriminada da teoria dos campos de Pierre Bourdieu como modelo de análise, já que o renomado sociólogo pouco escreveu a respeito do assunto e também porque seus escassos manuscritos têm um tom ensaístico em detrimento ao rigor científico pautado na análise e/ou interpretação de material empírico, é gerada a polêmica, tendo em vista que vários autores de capítulos da própria obra em questão se apoiaram neste modelo teórico. De forma alguma tal condição pode ser considerada um demérito! É parte constitutiva fundamental nas Ciências Sociais o estabelecimento de tensões. Assim sendo, é possível que a pertinente questão levantada por Rafael Fortes sirva de pauta futuramente para o debate acadêmico. É possível, então, que a querela lançada na obra História no Esporte no Brasil seja discutida em outros fóruns, como congressos, periódicos científicos ou até em outras obras de cunho acadêmico.

Destaca-se também que com temáticas e abordagens tão variadas, a intensidade com que cada autor interpretou o fenômeno esportivo oscilou sensivelmente. Enquanto alguns privilegiaram uma densa apropriação teórica conjugada à análise de fontes históricas, outros, devido à amplitude da temática, optaram por produzir um texto mais descritivo, centrado essencialmente da revisão historiográfica.

A publicação de obras organizadas com capítulos de autores distintos é uma tendência que visa atender a uma necessidade das Humanidades nas últimas décadas: o acentuar tanto do processo que gera a delimitação de temáticas quanto aos múltiplos métodos e técnicas do "fazer" história. Logo, a obra História do Esporte no Brasil: do Império aos dias atuais, formada por textos articulados que geram um sentido para o transcurso histórico de tais práticas, oferece aos pesquisadores do fenômeno esportivo e também ao público simplesmente curioso no assunto conhecimento inédito, ou seja, atende plenamente o seu objetivo.

Ao término da leitura, indiferente ao nível de conhecimento do leitor, é inevitável perceber que o esporte é um dos elementos mais complexos e relevantes da sociedade brasileira.

Recebido em:09.07.2017

Aceito em: 26.10.2017 